
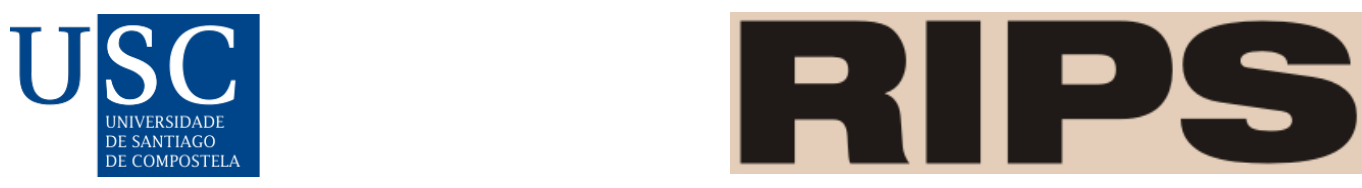

Revista

de Investigaciones

Políticas y Sociológicas

RIPS: Revista de Investigaciones Políticas y Sociológicas, 20(2), 2021. ISSN-e: 2255-5986

https://doi.org/10.15304/rips.20.2.7542

Recensiones de Libros

\title{
Javier Roiz. Sociedad vigilante y mundo judío en la concepción del Estado Madrid, Editorial Complutense, 2008
}

\section{Carlos Allones Pérez}

Universidade de Santiago de Compostela, Santiago de Compostela, España

carlosantonioj.allones@usc.es

El libro de Roiz es como un diamante que tiene muchas caras, muchas aristas. Aquí queremos comentar solamente aquellas facetas del libro que más directamente han servido a nuestros fines, animando a otros lectores a que hagan otros comentarios de este libro de tan variados intereses.

Por nuestra parte lo hemos leído sobre todo desde 3 puntos de vista: el de la Sociología Histórica, el de la Ciencia Política, y el de la Sociología de orientación tönnesiana.

Una interpretación sociológica de Américo Castro (2001) nos lleva a pensar que de las tres sociabilidades yuxtapuestas en la Península Ibérica durante la Edad Media, la islámica, la judía, y la católica, la última, finalmente triunfante, se hizo sobre todo militando en contra de las otras dos, sobre todo localmente, sobre todo cotidianamente, y sobre todo en contra de la casta judía. Por eso es importante el libro de Roiz desde el punto de vista de la Sociología Histórica, pues al revelarnos las impresionantes características de la cultura y sociabilidad sefardí, se nos revelan las nuestras, ya que posiblemente hechas a la contra: en desprecio a su laboriosidad, a su alfabetización, a su habilidad comercial y diplomática, a su medicina, a su sofisticado pensamiento sobre lo público... y a todo lo demás. Y no es algo que haya quedado en el pasado, superado por la expulsión de 1492, sino que nuestro sobre-ponderado familismo actual, nuestro incorregible particularismo (Moya, 1975), es en buena medida resultado de aquella nunca interrumpida elaboración cultural de siglos, que ha continuado (y continua todavía hoy) recreando, siempre actualizada, aquella militancia contrameritocrática.

En segundo lugar, también es importante el libro de Roiz en lo que se refiere a la construcción de una verdadera teoría política, una teoría política que sepa dar cuenta de los límites, cada vez más asfixiantes, de la sociabilidad occidental, y que no consista en una mera apología recurrente de la misma, incapaz de verse a sí misma desde fuera, y por ello incapaz de cuestionar sus propios fundamentos. Según Roiz, para la construcción de esa teoría política, Maimónides (1135-1204) ofrece un punto de partida distinto que el aristotélico, pues si el griego veía el fundamento de la sociedad humana en el lenguaje (y no le faltaba razón), Maimónides (1963) lo ve en la impotencia con la que el bebé se incorpora al mundo (y tampoco le falta). Pues es precisamente a partir de esa radical impotencia del infante, que la vida humana se convierte en una lucha compulsiva por afianzar el propio poder (libido dominandi). Creemos, con Roiz, que este concepto de Maimónides, puede ser la semilla, la piedra angular que fundamente una nueva teoría política, capaz verdaderamente de educar a la persona en su propio gobierno, algo que se echa cada vez más 
en falta en las sociedades occidentales de orientación calvinista, que el autor define como vigilantes, por razones que -una vez leído su libro- nos parecen obvias.

Finalmente, como sociólogos tönnesianos que somos, tenemos que agradecer al libro de Roiz que nos diera a conocer la existencia de los responsa. Los responsa eran respuestas que daban por escrito los Rabís a las consultas que, sobre todo tipo de temas, y también por escrito, les hacían los vecinos de las aljamas. Equivalen a un acta notarial de la vida cotidiana sefardí a lo largo de los siglos, un viaje directo al corazón de la vieja racionalidad patriarcal, que orientaba (para bien y para mal) al mundo pre-moderno, y especialmente en Iberia... Se me dirá, esos responsa recogen tan solo lo que ocurría en las vecindades en torno a una sinagoga, no en las católicas en torno a una iglesia o en las islámicas en torno a una mezquita. Cierto, pero esas tres comunidades, aún con sus diferentes improntas culturales, no podían sino abonarse a la racionalidad patriarcal que les era común en lo más profundo, ya que esa racionalidad era una característica inevitable de un modo de estructuración social que no habría de romperse (que no podía romperse) sino mucho más adelante, bajo la dominación capitalista más avanzada. Y resulta que nosotros, como sociólogos que somos, como tönnesianos que somos, y en contra de la opinión común, pensamos que, tener presente esa sabiduría patriarcal, es hoy en día más necesario que nunca... Pues como decía Antonio Machado en sus Canciones y Proverbios (1970: 370):

"Bueno es recordar

las viejas palabras

que han de volver a sonar".

En fin, animamos a los lectores en ciencias sociales (sobre todo ibéricos e iberoamericanos, pero no solo) a leer este libro de Javier Roiz -un libro que, con traducción de Selma L. Margaretten, ha sido publicado también por la Universidad del Estado de Nueva York en inglés en el año 2013. En la seguridad de que cada cual encontrará en sus páginas muchos temas de su interés. Pues en esas páginas resuenan las voces sabias de los grandes maestros sefardíes, voces antiguas, sí, pero cargadas de futuro, y que han sido generosamente actualizadas para nosotros por el profesor Roiz.

\section{Bibliografía}

CASTRO, Américo (2001): España en su Historia, Barcelona: Crítica.

MACHADO, Antonio (1970): Poesías Completas, Madrid: Austral.

MAIMONIDES, Moshe ben Maimon. (1963): The Guide of the Perplexed, Chicago: The University of Chicago Press. (Ensayo introductorio de Leo Strauss).

MOYA, Carlos (1975): El poder económico en España (1939-1970): Un análisis sociológico. Guadalajara: Tucar Ediciones

TÖNNIES, Ferdinand (1979): Comunidad y Asociación, Barcelona: Península. 